\title{
WHAT IS AN EXCELLENT PLACE TO WORK? DIFFERENCES IN THE PERCEPTION OF MEN AND WOMEN IN THE CONSTRUCTION SECTOR
}

\author{
O QUE É UM EXCELENTE LUGAR PARA TRABALHAR? \\ DIFERENÇAS NA PERCEPÇÃO DE HOMENS \\ E MULHERES NO SETOR DE CONSTRUÇÃO
}

\author{
Nágila Giovanna Silva Vilela ${ }^{1}$ \\ Lucas dos Santos Costa ${ }^{1}$ \\ Ronaldo de Oliveira Santos Jhunior ${ }^{1}$ \\ Adrian Ilie Olar ${ }^{2}$ \\ 1 Faculdade de Economia, Administração e Contabilidade - Universidade de São Paulo (FEA/USP). \\ São Paulo, São Paulo, Brazil. \\ 2 Tilburg School of Economics and Management - Tilburg University. \\ Tilburg, Noord-Brabant, The Netherlands.
}

Submission: 30/11/20 Accept: 09/04/21

\begin{abstract}
Purpose - The purpose of this paper is to examine gender differences between men and women on the factors that make an organization an excellent place to work. It is assumed that these factors are tangible or intangible.

Design/methodology/approach - Secondary data from 4460 workers in the construction sector who responded to the Best Companies to Work 2017 survey were used. The data were analyzed using descriptive statistics and Multinomial Logistic Regression. From the consideration of ten intangible aspects and one tangible aspect, differences between men and women were perceived in the definition of an excellent place to work. Findings - When compared to men, women are more likely to consider intangible aspects (six out of ten) than tangible in defining an excellent place to work. The other four intangible factors did not show significant differences between genders.

Practical implications - This research results can be useful for employers and managers, who should seek measures that contribute to making work more interesting and engaging for all workers.

Social implications - We seek to contribute to a better understanding of the gender differences associated with the workplace of a predominantly male environment. The social implications are associated with the need to highlight that inequality in the work environment is lingering still.

Originality/value - Despite the presence of progress in equalizing labor rights, there is still a long way to go and this research seeks to highlight this issue based on the analysis of reliable data.
\end{abstract}

Keywords: Gender; Construction sector; HR; Multinomial Logistic Regression. 


\section{RESUMO}

Objetivo - O objetivo deste artigo é examinar as diferenças de gênero entre homens e mulheres sobre os fatores que tornam uma organização um excelente lugar para trabalhar. Presume-se que esses fatores sejam tangíveis ou intangíveis.

Método - Foram utilizados dados secundários de 4460 trabalhadores do setor de construção que responderam à pesquisa Melhores Empresas para Trabalhar em 2017. Os dados foram analisados por meio de estatística descritiva e Regressão Logística Multinomial. A partir da consideração de dez aspectos intangíveis e um aspecto tangível, foram percebidas diferenças entre homens e mulheres na definição de um excelente local para trabalhar.

Resultados - Quando comparadas aos homens, as mulheres são mais propensas a considerar aspectos intangíveis (seis em cada dez) do que tangíveis na definição de um excelente lugar para trabalhar. Os outros quatro fatores intangíveis não apresentaram diferenças significativas entre os gêneros.

Implicações Práticas - Os resultados desta pesquisa podem ser úteis para empregadores e gestores, que buscam medidas que contribuam para tornar o trabalho mais interessante e envolvente para todos os trabalhadores.

Implicações Sociais - Procuramos contribuir para uma melhor compreensão das diferenças de gênero associadas ao ambiente de trabalho em um ambiente predominantemente masculino. As implicações sociais estão associadas à necessidade de destacar que a desigualdade no ambiente de trabalho ainda está presente.

Originalidade - Apesar de haver avanços na equalização dos direitos trabalhistas, ainda há um longo caminho a percorrer e esta pesquisa busca evidenciar essa questão a partir da análise de dados confiáveis.

Palavras-chave: Gênero; Setor de construção; RH; Regressão Logística Multinomial.

\section{INTRODUCTION}

$19^{\text {th }}$ century society, in general, was characterized by the sexual division of labor, in which the productive world belonged to men while the reproductive world belonged to women (Sousa \& Guedes, 2016). From the $20^{\text {th }}$ century, however, women increased their participation in the labor market and in the management of organizations as a result of socioeconomic changes and feminist movements (Sorj, Fontes, \& Machado, 2007; Almeida, Morais, \& Coelho, 2020). The "relaxation of the borders" (Sousa \& Guedes, 2016, p. 123) between these two worlds has contributed so that women, in addition to being housewives, also enter the job market over time (Beraldo \& Trindade, 2016, Sousa \& Guedes, 2016). Meanwhile, men, despite being aware of the cultural imposition of the father-provider pattern, do not know exactly how they should behave in order to adapt to the new demands (Beraldo \& Trindade, 2016), and, for this reason, they often stay away from the domestic world (Sousa \& Guedes, 2016).

In this perspective, the number of active women in the workforce has grown significantly over the past 50 years (Kim, Atwater, Jolly, Kim, \& Baik, 2019). Despite this, in Brazil, according to the Instituto Brasileiro de Geografia e Estatística, IBGE, - Brazilian Institute of Geography and Statistics, in free translation - the unemployment rate for women in 2017 was $14.6 \%$ while that for men was $12.5 \%$ (IBGE, 2019). This index shows an acceleration of female unemployment, which in 2014 was 8.5\% (IBGE, 2019).

In addition to the changes associated with the number of female workers, the world of work has undergone other transformations, such as the end of lifelong jobs, the emergence of new technologies, innovative ways of organizing work, prolonging professional life, possibilities of parttime work, among others (Wainwright et al., 2018, Oishi, Chan, Wang, \& Kim, 2015, Morin, 2001).

In view of the changes and diversification of the workforce, it is not surprising that individuals in the work environment have different perspectives on the various attributes of work. Therefore, 
the objective of this research is to examine the gender differences between men and women on the factors that make an organization an excellent place to work. It is admitted that the factors that contribute to an organization to be an excellent place to work are tangible or intangible. While the tangible aspects are the concrete ones, which can be touched and/or quantified, the intangible aspects ". . . are much more difficult to perceive and, mainly, to quantify" (Del Fiaco \& Melo, 2011, p. 49). The sector chosen for the research was construction, because in Brazil, according to the Statistics of the Central Register of Enterprises - CEMPRE, in Portuguese -, this is the sector that has the biggest difference between employed men and women, with male participation equivalent to $89.8 \%$ of the total (IBGE, 2018). To answer the proposed objective, secondary data from the 2017 Best Companies to Work (MEPT, in Portuguese) survey were used.

As some previous research has shown gender differences in relation to job attributes, such as satisfaction, motivation, and commitment, the assumption of this research is that men and women will have different perceptions about what is an excellent place to work. The research by Lee, Robertson, and Kim (2019), for example, demonstrated that the determinants of job satisfaction are different for men and women. Similarly, Štefko et al. (2017) identified that both job satisfaction and motivation are perceived differently between genders. Still regarding gender differences, Sloan (2017) noted that, compared to men, women are more likely to perceive solidarity in their co-workers and to have higher levels of commitment to public employment.

This research is justified, in the theoretical scope, for contributing to a better understanding of the gender differences associated with the workplace considering a predominantly male environment, the construction sector. As for the practical aspect, the results of this work can be useful for employers and managers, who, as Lee et al. (2019) mention, should seek measures that contribute to making work more interesting and engaging for all workers. In addition, even among the best Brazilian companies, most of them do not have specific practices for serving, attracting, and retaining women (Vilela, Hanashiro, \& Costa, 2020). The social justification is associated with the need to highlight that inequality in the work environment - which has existed since women entered the market - is still present (Cavero-Rubio, Collazo-Mazón, \&Amorós-Martínez, 2019). There is no denying the existence of progress in terms of equalizing labor rights, however, " . . . experience shows us that there is still a long way to go" (Cavero-Rubio et al., 2019, p. 1).

\section{THEORETICAL BACKGROUND}

This topic presents concepts about what is tangible and intangible, followed by the results of previous research that determined, in some way, what is (or should be) an excellent place to work. The tangible and intangible aspects of the workplace are summarized in Table 1. As the mentioned researches do not differentiate between what is tangible or not, the classification presented was achieved by the authors of this paper based on the concepts covered in subtopic 2.1.

\subsection{Tangible versus intangible}

The concepts of tangible and intangible are present mainly in Accounting literature. While tangible assets are concrete and with physical substance - such as machines, real estate, and inventory - intangible assets are ". . represented by assets and rights for the use of a company to generate present and future benefits"(Dantas, 2017, p. 100). Intangible assets are invisible, therefore, they have no physical existence, such as software, patents, databases, franchises, relationships with suppliers and other stakeholders, customer loyalty, among others (Dantas, 2017, Kayo \& Famá, 2004). 
In the area of Quality Management, these concepts are also used: products are considered tangible and services are intangible. Thus, products can be touched and (sometimes) tasted before consumption, while it is not possible to touch, feel or taste a service before purchase (Fadel $\&$ Regis Filho, 2009). For this reason, product and service management are quite different. The difficulty in standardizing services, the need for production and consumption to happen simultaneously and the impossibility of being stocked create obstacles for inspection and control to be accomplished (Fadel \& Regis Filho, 2009).

Kurt, Sinkovics, Sinkovics, and Yamin (2020) also presented the concepts of tangible and intangible resources. The aim of these authors' research was to investigate the role of religion and spirituality in a business network context, focusing on the international business development of small Turkish companies. For the authors, through business networks, companies can have access to tangible and intangible resources. While tangible resources include ". . . access to distribution channels, logistics support, and input factors such as raw materials, machinery, and other equipment", intangible resources include ". . . know-how about foreign market entry, the identification of potential foreign customers, risk management, customer needs and trends" (Kurt et al., 2020, p. 4).

Kolpakova, May, and Maar (2019), on the other hand, deal with what is tangible and intangible when distinguishing the workplace and workspace. According to the authors, the workplace is physical and tangible and includes items such as furniture and equipment, while the workspace is not necessarily connected to a "real workplace", covering items such as organizational knowledge and business processes.

Based on the definitions presented, in this work the tangible aspects that contribute to making the workplace an excellent place to work include objective factors such as remuneration, benefits, or concrete policies. Intangible aspects, however, concern untouchable factors, such as autonomy, recognition, motivation, balance between personal and professional life, good working climate, among others. These tangible and intangible aspects will be discussed below.

\subsection{What makes a company an excellent place to work?}

Research that deals with the characteristics of an excellent place to work are usually associated with the meaning of work, since "work, today, is visibly valued, not only for the financial return but for the moral value it assumes in our culture"(Rizzo \& Chamon, 2010, p. 408). Morin (2001) quotes Emery $(1964,1976)$ and Trist $(1978)$ to determine the six properties of work that stimulate the commitment of those who do it: (1) variety and challenge; (2) continuous learning; (3) autonomy; (4) recognition and support from third parties in the organization; (5) social contribution; and (6) the possibility of improvement and professional guidance in the future.

In 2004, Coda and Fonseca performed qualitative research with 15 Brazilian executives to understand the meaning of work. The authors identified ten categories of meanings attributed to the work: (1) means of participating in something, being part; (2) independence, autonomy; (3) an instrument for transforming society and the organization; (4) means of building something, carrying out work; (5) knowledge expansion, development; (6) means of helping, contributing to people and society, being useful; (7) means of testing one's skills, overcoming one's limits; (8) possibility of relating and establishing links with people; (9) means of expression of knowledge and skills; (10) security, personal and family maintenance. The meaning attributed to work, therefore, expresses the wishes and needs of individuals, and the work itself is the instrument for such desires and needs to be fulfilled (Coda \& Fonseca, 2004). For the authors, “. . . as the work can fulfill its function, that is to say, the meaning attributed to it, there is a feeling of gratification and pleasure" (Coda \& Fonseca, 2004, p. 18). Thus, the job will be excellent for an individual if it is able to do theirfunction. In addition, 
each worker can assign one or more meanings to the work (Coda \& Fonseca, 2004).

The research by Cavazotte, Lemos and Viana (2012) sought to meet the expectations of young professionals in training relating to the tangible and intangible rewards they want to obtain at work. The authors realized, from the interviewees' report, that the tangible (wage increase) or symbolic (employee of the month) rewards have not been shown to be sufficient for young people, who prefer rewards in the form of constant attention and feedback. As the gender of the students was not presented, it was not possible to analyze whether there were gender differences regarding the preference of tangible or intangible rewards.

Lindberg and Vingård (2012), in turn, made a systematic review of the literature in order to know the indicators of healthy work environments, also called indicators of "a good place to work". According to the authors, good places to work have characteristics such as recognition, autonomy, growth and development, safe physical work, balance between work and life, and benefits for society (Lindberg \&Vingård, 2012).

The research by Souza, Lopes, and Hilal (2015) aimed to describe and analyze the characteristics of the work considered relevant for twenty-one Brazilian women workers in managerial positions. Among other relevant characteristics, the following can be mentioned: (1) identification with the work scope, especially when the work contributes to the company's results; (2) autonomy; (3) work climate, that is, a pleasant and comfortable environment for carrying out the work; (4) admiration by peers and by employees of other hierarchical levels, since, according to the interviewees "... it is relevant to work in a company that is, in some way, managed and led by people they respect and admire" (Souza et al., 2015, p. 121); (5) feedbacks, whether formal or informal; (6) wage level and indirect benefits; and (7) existence of social projects in the company (Souza et al., 2015).

Finally, based on the idea that individuals consider the organization's reputation when applying for job offers, Catano and Hines (2016) examined how much corporate social responsibility (CSR) and psychologically healthy workplace (PHW) policies were attractive to millennial generation' job seekers (that is, those born between 1979 and 1994). While CSR is associated with the organization's interest in promoting social policies that improve the relationship with society, PHW involves policies of balance between work and personal life, growth, and development of workers, health and safety, as well as recognition and involvement of employees (Catano \& Hines, 2016). The experimental study by Catano and Hines (2016) was carried out with 116 undergraduate students from Canada and revealed that candidates are more attracted by job advertisements that provide information on CSR and PHW policies. Although the majority (69\%) of the sample was composed of women, the authors did not analyze gender differences concerning the attraction of CSR and PHW policies and suggested that future research should investigate whether there are differences in this regard.

Based on the previous considerations, Table 1 summarizes the tangible and intangible aspects of the workplace in the cited researches. 
Table 1: Tangible and intangible aspects of the workplace

\begin{tabular}{|c|c|}
\hline Tangible aspects & Intangible aspects \\
\hline $\begin{array}{l}\text { The wage level and indirect benefits (Souza et al., } \\
2015 \text { ) }\end{array}$ & $\begin{array}{l}\text { Autonomy (Morin, 2001, Coda \& Fonseca, 2004, } \\
\text { Lindberg \&Vingård, 2012, Souza et al., 2015) }\end{array}$ \\
\hline $\begin{array}{l}\text { Possibility of acquiring material goods through } \\
\text { remuneration (Coda \& Fonseca, 2004) }\end{array}$ & $\begin{array}{l}\text { Continuous learning, growth and development, } \\
\text { knowledge expansion (Morin, 2001, Coda \& Fonseca, } \\
\text { 2004, Lindberg \&Vingard, 2012). }\end{array}$ \\
\hline Wage increase (Cavazotte et al., 2012) & $\begin{array}{l}\text { Variety and challenge, testing your own skills, and } \\
\text { overcoming your own limits (Morin, 2001, Coda \& } \\
\text { Fonseca, 2004) }\end{array}$ \\
\hline $\begin{array}{l}\text { Symbolic reward as an employee of the month } \\
\text { (Cavazotte et al., 2012) }\end{array}$ & $\begin{array}{l}\text { Attention and constant feedback (Cavazotte et al., } \\
\text { 2012, Souza et al., 2015) }\end{array}$ \\
\hline $\begin{array}{l}\text { Miscellaneous benefits package (Catano \& Hines, } \\
\text { 2016) }\end{array}$ & $\begin{array}{l}\text { Social contribution, benefit to society (Morin, 2001, } \\
\text { Coda \& Fonseca, 2004, Lindberg \&Vingård, 2012, } \\
\text { Souza et al., 2015) }\end{array}$ \\
\hline Safe physical work (Lindberg \&Vingård, 2012) & Recognition (Lindberg \&Vingård, 2012) \\
\hline $\begin{array}{l}\text { Balance policy between work and family: } 10 \text { family } \\
\text { days a year (Catano \& Hines, 2016) }\end{array}$ & Work-life balance (Lindberg \&Vingård, 2012) \\
\hline \multirow[t]{4}{*}{$\begin{array}{l}\text { Environmental sustainability policy and reduction of } \\
\text { paper waste (Catano \& Hines, 2016) }\end{array}$} & Work climate (Souza et al., 2015) \\
\hline & $\begin{array}{l}\text { Admire peers and employees from other hierarchical } \\
\text { levels (Souza et al., 2015) }\end{array}$ \\
\hline & Identification with the work scope (Souza et al., 2015) \\
\hline & $\begin{array}{l}\text { All employees are treated in the same way (Catano \& } \\
\text { Hines, 2016) }\end{array}$ \\
\hline
\end{tabular}

Source: the authors (2021) based on the cited research.

In this study, we assume that the tangible and intangible aspects will be perceived differently among male and female workers in the construction sector. Such consideration is associated with the finding of gender differences in relation to several research aspects. In research on faculty members, for instance, Webber and Rogers (2018) identified that, in relation to men, women perceive that recognition, mentoring and the balance between job functions are more important for their job satisfaction. As for work-life balance policies, although they are available for men and women, “. . .they are often viewed as mechanisms for enhancing women's experiences in the workplace" (Feeney \& Stritch, 2019, p. 429). This is because family responsibilities still fall disproportionately on women and the presence of such policies can contribute to equity in the workplace (Feeney \& Stritch, 2019).

After presenting the theoretical background, the following topic presents the methodological procedures that guide the research.

\section{METHODOLOGICAL PROCEDURES}

This quantitative and descriptive research aims to examine gender differences between men and women on the factors that make an organization an excellent place to work. To answer the proposed objective, secondary data from the 2017 MEPT survey were used. The survey contains information on 365 companies from various sectors such as engineering and construction, retail trade, technology and communication, health services, cooperative, agribusiness, among others. In total, 250,273 workers from these 365 companies participated in the survey, $76.6 \%$ of the answers are valid for the present study $(n=191,618)$, since it contains the answers used in the chosen variables. 
Eight companies of the Engineering and Construction sector participated in the 2017 MEPT survey. They had 8,746 employees, and $73.5 \%(n=6,426)$ responded to at least one question. Moreover, we removed two groups from the final analysis: 274 were non-heterosexual and/or non-cisgender, which is out of our research scope, and 1,692 did not know/desire to respond to at least one question. The total sample comprised 4,460 valid answers ( $72.5 \%$ of the 6,152 eligible to respond).

The data analysis techniques used were descriptive statistics (arithmetic mean, standard deviation, and proportions) and Multinomial Logistic Regression (MLR). The MLR assesses the probability of an event occurring and identifies characteristics of the elements belonging to each group determined by the categorical variable as a dependent (Fávero, Belfiore, Silva, \& Chan, 2009, p. 441). In this research, the use of this technique presents the relative risk of choosing an intangible aspect over a tangible aspect when characterizing the company as an excellent place to work by an independent variable, namely: gender controlled for other profile characteristics (educational level, age, company position, etc.). Therefore, the base/reference category chosen was the only one among the possible answers - identified as tangible, namely: remuneration. Thus, the key question used for this research was the following: what makes me consider a company an excellent place to work? Possible responses included:

- To be recognized for my dedication, for my new ideas and realize that my effort contributes to the company's success (Recognition);

- Feeling satisfied and motivated with the work 1 do in the company (Satisfaction and motivation);

- To agree with the company's goals and values and be proud to work for it (Objectives and values);

- Being able to balance my work and my personal life (Work-life balance);

- To admire what the company does for its customers, society and the community (Admiration);

- To realize that I am learning more and more and that I have the opportunity to grow and develop (Learning and growth);

- To have stability and security (Stability and security);

- To be in an environment of good relations with co-workers (Good relations);

- To receive a wage according to my responsibilities and a benefits package that meets my needs - reference category for comparisons (Wage and benefits);

- To be treated fairly (Fair);

- To have bosses that I respect, trust, and guide their work team (Respect and trust).

We use the software Stata/IC 15.1to treat the database, test the hypothesis, and construct the model. The processing of data occurred with the use of five main packages: mvdecode (separation of valid and non-valid responses), replace and recode (organization of categories), gen, and egen (creation of variables). The analyzes, hypothesis tests, and model construction were performed using several descriptive statistics packages, as tabulate and tabstat. Furthermore, multivariate analysis was based on mlogit for MLR and several post-estimation commands to assess the quality of the models: Hosmer-Lemeshow adapted to MLR (Fagerland \& Hosmer, 2012), general null hypothesis of the model that all parameters are equal to zero, and Pseudo- $R^{2}$ (total explained variability of the dependent variable). 


\section{ANALYSIS AND DISCUSSION OF RESULTS}

The research results are divided into four topics. The first one characterizes the sample by variable, in addition to describing them. The second presents the initial results of gender differences in the dependent variable. The third describes the relationship between control variables and the dependent variable, presenting complementary results. The fourth and last topic presents the results of the gender difference and an alternative model with the interaction between gender and the other variables, in order to detail the results.

\section{Description of variables and sample characterization}

The variables gender, identity, and sexual orientation were used as a filter to select part of the sample. In the process of cleaning the database, it was taken into account the selection of workers in the civil construction sector, heterosexuals (97.6\% workers), cisgenders $(99.5 \%$ are workers who identify with the sex that was born), who completely answered the questionnaire, and have a reason among those listed to choose a company as an excellent place to work. In total for the sector, $83 \%$ of workers declared to be male, 23 percentage points (pp) more than the other sectors. This number confirms the Statistics of the Central Register of Enterprises, which show that the construction sector has the greatest difference between men and women, with male participation equivalent to $89.8 \%$ of the total (IBGE, 2018).

The control variables in the relation between gender and the choice of an aspect (tangible or intangible) to consider a company as good to work are "Age", "Internship" (62 unanswered observations), "Work formal contract" (429 unanswered observations), "Position" (559 unanswered observations), "Wage" (4.4\% of respondents did not want to report their wage level, which is equivalent to 281 unanswered observations), "Education" (4.6\% of respondents did not report their level of instruction, which corresponds to 293 unanswered observations), "Disability" (2.9\% of respondents did not report whether they had any type of disability, which corresponds to 185 unanswered observations), "Number of children" (2.7\% of respondents did not inform the number of children, which corresponds to 170 unanswered observations) and "Ethnicity" (3.7\% of respondents did not inform ethnicity, which is equivalent to 236 unanswered observations).

The average age of workers is 38.6 years $(s=9.9)$. On average $(p<0.01)$, men (39.4 years; $s=10$ ) in the construction sector are almost five years older than women (34.7 years; $s=8.6$ ). Most workers have an employment relationship with the company (94.8\%), that is, they are employees and not interns. Most workers in the sector are formally hired following the Consolidation of Labor Laws (CLT) valid in Brazil (64.8\%).

Most workers in the sector have an operational position (81.8\%), with $5 \mathrm{pp}$ more men and $3 p p$ more women when compared to other sectors. This observation can be explained by the nature of the sector itself, which needs more operational workforce. Regarding wages, $36.2 \%$ of construction workers declared that they receive up to 2 minimum wages, 31\% receive between two and four, and $32.8 \%$ receive more than four minimum wages. We identify that these proportions do not differ by more than $1 \mathrm{pp}$ from what was observed in the proportions found in the complete data set, reflecting that the wage reality of the construction sector sample is equivalent to that observed in the other sectors. When comparing with the other sectors, there are $10 \mathrm{pp}$ fewer women who earn up to 2 minimum wages and $14 p p$ more women who earn more than 4 minimum wages. The proportions of men do not differ from those observed in the market.

As for the level of education, $53 \%$ of the workers have completed high school, $30.2 \%$ 
have higher education and $16.8 \%$ have taken a postgraduate course. The construction sector has a discrepancy when compared to the others, as it reaches $13 \mathrm{pp}$ more people in the less educated level, $8 p p$ fewer graduates in higher education, and $5 p p$ fewer postgraduates. When contrasting gender differences, there are 10pp more women with postgraduate degrees and 8pp more men with only high school education in this sector than in the others.

In the construction sector, the proportion of disabled people (4.2\%) is slightly higher than in the other sectors (4\%), but it is still clear that most of the sample declared they were not disabled. There are no significant differences (greater than 1pp) between disabled men and women in the construction sector compared to the rest. As for the number of children, about $35.7 \%$ of workers in the construction and engineering sector do not have children, $27.3 \%$ have only one child and $37 \%$ have two or more children. Most construction workers have two or more children, while in the other sectors the predominant category is that of not having children (44.2\%). The proportion of women who work in the sector and do not have children is higher than that observed in the market ( $8 p p)$; the opposite is observed with men (less $7 p p$ ).

Concerning ethnicity, $60 \%$ are white and $40 \%$ non-white. Among non-whites, $26.4 \%$ are brown/mulatto, $8.1 \%$ are black, $4.9 \%$ are yellow and $0.6 \%$ are indigenous. There are no variations greater than $1 \mathrm{pp}$ on ethnicity between the construction sector and the other sectors in each of the categories mentioned.

\section{The proportion of men and women in the perceptions of an excellent place to work}

In this research, the dependent variable includes 11 factors that characterize a company as an excellent place to work. Among these factors, ten are intangible and one is tangible (reference category for comparisons). Table 2 summarizes the absolute and relative frequency of the tangible and intangible preferences to a company to be considered an excellent place to work.

Among the answers to the question of an excellent place to work, the most frequent for men is "agreeing with the company's goals and values and being proud to work for it" $(18.7 \%, n=$ 782), whereas the least frequent is "having bosses that I respect, trust and that guide their work team" $(1.1 \%, n=49)$. For women, the most frequent answer is "to realize that I am learning more and more and that I have the opportunity to grow and develop" $(3.9 \%, n=183)$, and less frequently is "to be treated fairly" $(0.2 \%, \mathrm{n}=7)$.

For both men $(72.2 \%)$ and women $(77.4 \%)$, most preferences for considering a company as an excellent place to work are concentrated in the first four options in Table 2. These four options represent intangible aspects which are proportionally preferable for men and women at the expense of receiving an adequate wage and benefits package (men $=10.8 \%$ and women $=6.7 \%$ ). Henceforth, we observe that wage is not a sine qua non condition to consider that a company is excellent to work, a result that is in line with the one mentioned by Rizzo and Chamon (2010). Despite this, relatively, men choose more frequently (4pp more) to receive an adequate wage and benefits package than women.

The other categories less frequent than the wage for men and women are, respectively: having an environment with good relations ( $5.6 \%$ and $4.4 \%$ ), a balance between work and personal life $(3.7 \%$ and $5.3 \%)$, stability and security ( $2.5 \%$ and $1.8 \%)$, admiring actions taken by the company $(2.3 \%$ and $1.3 \%)$, fair treatment $(1.7 \%$ and $0.9 \%)$ and having a respect and trust relationship with the boss (1.3\% and $2.2 \%)$.

Three categories presented different percentages between the construction sector and the other sectors, they are: "agree with the company's goals and values and be proud to work 
in it" (3pp higher in the construction sector), "feel satisfied and motivated with the work I do in the company" (3pp higher in other sectors) and "being in an environment of good relations with co-workers" (2pp higher in the construction sector).

Table 2: Gender differences in the responses attributed to the question: "What makes me consider a company to be an excellent place to work?"

\begin{tabular}{|c|c|c|c|c|c|c|c|c|}
\hline \multirow[b]{3}{*}{ Abbreviation } & \multicolumn{2}{|l|}{ Frequency } & \multicolumn{3}{|l|}{ Men } & \multicolumn{3}{|l|}{ Women } \\
\hline & \multirow[b]{2}{*}{ Absolute } & \multirow[b]{2}{*}{ Relative } & \multirow[b]{2}{*}{ Absolute } & \multicolumn{2}{|l|}{ Relative } & \multirow[b]{2}{*}{ Absolute } & \multicolumn{2}{|l|}{ Relative } \\
\hline & & & & General' $^{1}$ & Gender $^{2}$ & & General $^{1}$ & Gender $^{2}$ \\
\hline $\begin{array}{l}\text { Objectives and } \\
\text { values }\end{array}$ & 1013 & $21.7 \%$ & 872 & $18.7 \%$ & $22.5 \%$ & 141 & $3.0 \%$ & $17.9 \%$ \\
\hline $\begin{array}{l}\text { Satisfaction } \\
\text { and motivation }\end{array}$ & 848 & $18.2 \%$ & 675 & $14.5 \%$ & $17.4 \%$ & 173 & $3.7 \%$ & $21.9 \%$ \\
\hline $\begin{array}{l}\text { Learning and } \\
\text { growth }\end{array}$ & 793 & $17.0 \%$ & 610 & $13.1 \%$ & $15.8 \%$ & 183 & $3.9 \%$ & $23.2 \%$ \\
\hline Recognition & 752 & $16.1 \%$ & 638 & $13.7 \%$ & $16.5 \%$ & 114 & $2.4 \%$ & $14.4 \%$ \\
\hline $\begin{array}{l}\text { Wage and } \\
\text { benefits }(\mathrm{T})\end{array}$ & 471 & $10.1 \%$ & 418 & $9.0 \%$ & $10.8 \%$ & 53 & $1.1 \%$ & $6.7 \%$ \\
\hline Good relations & 250 & $5.4 \%$ & 215 & $4.6 \%$ & $5.6 \%$ & 35 & $0.8 \%$ & $4.4 \%$ \\
\hline $\begin{array}{l}\text { Work-life } \\
\text { balance }\end{array}$ & 187 & $4.0 \%$ & 145 & $3.1 \%$ & $3.7 \%$ & 42 & $0.9 \%$ & $5.3 \%$ \\
\hline $\begin{array}{l}\text { Stability and } \\
\text { security }\end{array}$ & 111 & $2.4 \%$ & 97 & $2.1 \%$ & $2.5 \%$ & 14 & $0.3 \%$ & $1.8 \%$ \\
\hline Admiration & 98 & $2.1 \%$ & 88 & $1.9 \%$ & $2.3 \%$ & 10 & $0.2 \%$ & $1.3 \%$ \\
\hline Fair & 71 & $1.5 \%$ & 64 & $1.4 \%$ & $1.7 \%$ & 7 & $0.2 \%$ & $0.9 \%$ \\
\hline $\begin{array}{l}\text { Respect and } \\
\text { trust }\end{array}$ & 66 & $1.4 \%$ & 49 & $1.1 \%$ & $1.3 \%$ & 17 & $0.4 \%$ & $2.2 \%$ \\
\hline Totals & 4660 & $100.0 \%$ & 3871 & $83.1 \%$ & $100.0 \%$ & 789 & $16.9 \%$ & $100.0 \%$ \\
\hline
\end{tabular}

${ }^{1}$ Relative frequency in relation to total responses.

${ }^{2}$ Relative frequency in relation to the total number of responses for each gender, separately.

T: Tangible aspect.

Source: the authors (2020) based on data from the 2017 MEPT survey.

\section{Interpretation of control variables}

Table 3 shows the final results of the multinomial logistic model, which achieved a good overall fitbased on the Hosmer-Lemeshow test adapted to the MLR (Fagerland \& Hosmer, 2012), with the non-rejection of the null hypothesis $\left(\chi^{2}=76.91 ; \mathrm{df}=80 ; p=0.58\right)$. It is possible to reject the model null hypothesis of the general test if all parameters are equal to zero $\left(\chi^{2}=625.2\right.$; $d f$ $=140 ; p<0.01$ ). Not all variables that fully explain the phenomenon have been included - that is, what makes a construction worker consider a company an excellent place to work - this paper only controls gender differences by profile characteristics. Which justifies the low value of Pseudo- $R^{2}=3.3 \%$ in the total explanation of the aspect. The interpretation of this coefficient of determination suggests that other conditions - more specifically, variables - are responsible for explaining the completeness of the phenomenon in observation. 
Older workers are slightly associated with the preference of certain intangible factors over the tangible, such as stability and security ( $r r=1.03 ; p=0.04)$, being treated fairly ( $r r r=$ 1.04; $p=0.08$ ) and agree with the company's values and objectives ( $r r=1.01 ; p=0.09$ ). On the other hand, younger workers prefer learning, growth, and development over wages and benefits ( $r r r=0.96 ; p<0.01)$. Another category that is associated with the preference of younger people, when compared to wage and benefits, is the recognition for their dedication, for new ideas, and for knowing that they are contributing to the company's success ( $r r=0.99 ; p=0.10)$. In the other categories, age variation is not associated with an increase in the probability of choosing an intangible over the tangible aspect.

Interns, compared to workers with formal contracts (CLT), are more likely to choose six out of ten intangible aspects, at the expense of an adequate wage and benefits package. They are four times riskier to choose a company as an excellent place to work when they admire the company's activities $(p=0.05) ; 3.2$ times when they have the opportunity to learn, grow and develop $(p=0.01) ; 2.9$ times when there are good relations with the boss $(p=0.05)$ or balance between work and personal life $(p=0.08) ; 2.7$ times when they feel satisfied and motivated $(p=0.03)$; and 2.4 times when they agree with the company's goals and values $(p=0.07)$.

Being treated fairly was only preferable to receiving a compatible wage and benefits in two situations: (1) employees with disabilities are 4.3 times $(p=0.01)$ riskier than employees without disabilities to consider this aspect, and (2) employees formally hired (CLT) in relation to those not hired under this contract, with a risk 1.9 times greater $(p=0.07)$. Nevertheless, in relation to the disabled people, they have a preference for other intangible aspects at the expense of wage, when compared to the non-disabled, thus, the possibility of learning, growth, and development (risk 2.4 times higher than the non-disabled; $p=0,02$ ); recognition for dedication to the company (2.4 times higher than non-disabled people; $p=0.02$ ); and satisfaction and motivation with the work performed (2.1 times greater than the non-disabled; $p=0.05$ ).

Considering the wage, workers who are in the lowest salary range - earning up to 2 minimum wages - are riskier to choose a company as excellent to work due to intangible aspects at the expense of wage and benefits. When compared to those who earn between 2 and 4 salaries, those with a lower wage range opted for four intangible aspects and when compared to those who earn more than four salaries, they opted for five intangible aspects. Between these aspects, three categories are common in both analyzes: having an environment of good relations with co-workers ( $p$ $=0.01)$, having stability and security $(p<0.01)$ and learning, growth, and development $(p<0.01)$. 
Table 3: General research model

\begin{tabular}{|c|c|c|c|c|c|c|c|c|c|c|c|c|c|c|c|c|c|c|c|c|}
\hline \multirow{2}{*}{$\begin{array}{c}\text { Wage and } \\
\text { benefits } \\
\text { (Reference) }\end{array}$} & \multicolumn{2}{|c|}{ Admiration } & \multicolumn{2}{|c|}{$\begin{array}{l}\text { Objectives } \\
\text { and values }\end{array}$} & \multicolumn{2}{|c|}{$\begin{array}{c}\text { Work-life } \\
\text { balance }\end{array}$} & \multicolumn{2}{|c|}{$\begin{array}{c}\text { Good } \\
\text { relations }\end{array}$} & \multicolumn{2}{|c|}{$\begin{array}{l}\text { Learning and } \\
\text { growth }\end{array}$} & \multicolumn{2}{|c|}{$\begin{array}{l}\text { Satisf. and } \\
\text { motivation }\end{array}$} & \multicolumn{2}{|c|}{ Recognition } & \multicolumn{2}{|c|}{ Fair } & \multicolumn{2}{|c|}{$\begin{array}{c}\text { Respect and } \\
\text { trust }\end{array}$} & \multicolumn{2}{|c|}{$\begin{array}{c}\text { Stability and } \\
\text { security }\end{array}$} \\
\hline & $\mathrm{rrr}$ & $\mathrm{p}$ & $\mathrm{rrr}$ & $\mathrm{p}$ & $\mathrm{rrr}$ & $\mathrm{p}$ & $\mathrm{rrr}$ & $\mathrm{p}$ & $\mathrm{rrr}$ & $\mathrm{p}$ & $\mathrm{rrr}$ & $\mathrm{p}$ & $\mathrm{rrr}$ & $\mathrm{p}$ & $\mathrm{rrr}$ & $\mathrm{p}$ & $\mathrm{rrr}$ & $\mathrm{p}$ & $\mathrm{rrr}$ & $\mathrm{p}$ \\
\hline Age & 1.02 & 0.14 & 1.01 & 0.09 & 0.99 & 0.37 & 1.00 & 0.71 & 0.96 & 0.00 & 0.99 & 0.43 & 0.99 & 0.10 & 1.03 & 0.08 & 1.02 & 0.15 & 1.03 & 0.04 \\
\hline Intern & 4.00 & 0.05 & 2.42 & 0.07 & 2.92 & 0.08 & 2.94 & 0.05 & 3.17 & 0.01 & 2.73 & 0.03 & 1.76 & 0.25 & 0.00 & 0.99 & 2.25 & 0.37 & 2.55 & 0.23 \\
\hline $\begin{array}{l}\text { Work } \\
\text { Formal } \\
\text { Contract }\end{array}$ & 1.03 & 0.90 & 1.04 & 0.77 & 1.22 & 0.37 & 1.86 & 0.00 & 1.33 & 0.05 & 1.13 & 0.36 & 0.93 & 0.58 & 1.87 & 0.07 & 2.77 & 0.01 & 1.83 & 0.04 \\
\hline \multicolumn{21}{|l|}{ Operational } \\
\hline Tactical & 1.71 & 0.19 & 2.02 & 0.00 & 1.47 & 0.20 & 0.67 & 0.34 & 2.21 & 0.00 & 1.49 & 0.08 & 1.87 & 0.01 & 1.87 & 0.20 & 1.34 & 0.63 & 1.49 & 0.35 \\
\hline Strategic & $3 E+6$ & 0.99 & $8 \mathrm{E}+6$ & 0.98 & $3 \mathrm{E}+6$ & 0.99 & $3 E+6$ & 0.99 & $5 \mathrm{E}+6$ & 0.99 & $3 \mathrm{E}+6$ & 0.99 & $4 \mathrm{E}+6$ & 0.99 & 1.51 & 1.00 & 1.99 & 1.00 & 1.20 & 1.00 \\
\hline \multicolumn{21}{|l|}{$<2$ salaries } \\
\hline $\begin{array}{l}\text { Between } 2 \\
\text { and } 4\end{array}$ & 0.76 & 0.37 & 0.94 & 0.70 & 0.89 & 0.66 & 0.55 & 0.01 & 0.62 & 0.00 & 0.70 & 0.03 & 0.98 & 0.92 & 0.69 & 0.27 & 0.70 & 0.28 & 0.56 & 0.04 \\
\hline$>4$ salaries & 0.53 & 0.10 & 1.06 & 0.76 & 1.01 & 0.96 & 0.47 & 0.01 & 0.46 & 0.00 & 0.74 & 0.13 & 0.74 & 0.13 & 0.50 & 0.11 & 0.36 & 0.03 & 0.43 & 0.02 \\
\hline \multicolumn{21}{|l|}{$\begin{array}{l}<\text { High } \\
\text { School }\end{array}$} \\
\hline Graduate & 1.24 & 0.51 & 0.74 & 0.06 & 1.78 & 0.03 & 0.73 & 0.18 & 1.24 & 0.20 & 1.14 & 0.44 & 0.99 & 0.97 & 1.01 & 0.99 & 0.84 & 0.66 & 0.91 & 0.78 \\
\hline Postgrad. & 1.43 & 0.40 & 0.65 & 0.04 & 2.02 & 0.03 & 0.65 & 0.19 & 1.18 & 0.47 & 1.19 & 0.42 & 0.73 & 0.17 & 0.66 & 0.44 & 0.68 & 0.48 & 0.89 & 0.79 \\
\hline Disabled & 0.50 & 0.51 & 1.30 & 0.48 & 2.19 & 0.12 & 1.17 & 0.77 & 2.42 & 0.02 & 2.05 & 0.05 & 2.37 & 0.02 & 4.28 & 0.01 & 2.15 & 0.26 & 0.00 & 0.98 \\
\hline \multicolumn{21}{|l|}{$\begin{array}{l}\text { No } \\
\text { Children }\end{array}$} \\
\hline 1 child & 1.09 & 0.77 & 0.84 & 0.26 & 1.10 & 0.67 & 0.59 & 0.02 & 0.62 & 0.00 & 0.81 & 0.17 & 0.80 & 0.16 & 0.76 & 0.46 & 0.51 & 0.07 & 0.80 & 0.46 \\
\hline 2 or more & 0.69 & 0.28 & 0.87 & 0.40 & 1.02 & 0.93 & 0.64 & 0.05 & 0.71 & 0.05 & 0.78 & 0.16 & 0.87 & 0.43 & 0.90 & 0.77 & 0.61 & 0.20 & 0.95 & 0.88 \\
\hline White & 1.06 & 0.83 & 1.06 & 0.62 & 1.17 & 0.43 & 0.70 & 0.04 & 0.98 & 0.90 & 0.89 & 0.37 & 0.94 & 0.62 & 0.91 & 0.73 & 0.87 & 0.63 & 0.91 & 0.68 \\
\hline Woman & 0.76 & 0.48 & 1.40 & 0.07 & 1.64 & 0.04 & 1.30 & 0.30 & 1.57 & 0.01 & 1.66 & 0.01 & 1.38 & 0.09 & 1.05 & 0.91 & 3.05 & 0.00 & 1.32 & 0.42 \\
\hline Constant & 0.11 & 0.00 & 1.39 & 0.26 & 0.26 & 0.01 & 1.07 & 0.86 & 9.54 & 0.00 & 2.52 & 0.00 & 3.30 & 0.00 & 0.05 & 0.00 & 0.05 & 0.00 & 0.09 & 0.00 \\
\hline
\end{tabular}

Explanation: relative risk ratios (rrr), $\mathrm{p}$-value (p). Values in bold have at least $\mathrm{p}<0.1$.Empty Lines: reference categories.

Source: the authors (2021) based on the 2017 MEPT survey data.

Workers with higher educational levels, either undergraduate ( $r r=1.8 ; p=0.03$ ) or postgraduate ( $r r=2.02 ; p=0.03$ ), are only more reckless to choose an intangible aspect at the expense of wage and benefits package when this aspect is related to the balance between work and personal life. Who have, at most, high school are the ones who prefer wage than compatibility with the company's objectives and values, when compared to those with higher education - graduate $(p=0.06)$ and postgraduate $(p=0.04)$. The educational level is homogeneous in the other comparisons between intangible and tangible aspects.

\section{Gender differences in the perception of an excellent place to work}

When analyzing the central variable of the study - gender, we found that men and women have different preferences to consider a company as excellent to work. This finding demonstrates that in addition to the differences between men and women regarding job satisfaction (Lee et al., 2019), motivation (Štefko et al., 2017) and perceptions of solidarity between co-workers (Sloan, 2017 ), for instance, workers also have different preferences about what is an excellent place to work. In a general analysis, we observe the predominance in the choice of women for certain intangible aspects. In the comparison between the ten categories of intangible and the tangible aspect (wage), men and women have an equivalent preference for four intangible aspects. Women, more than men, prefer six other intangible aspects at the expense of wage, as discussed below, in order, from what is most different to what is less.

The biggest discrepancy between men and women occurs in the aspect "having bosses that I respect, trust and guide their work team". Women are three times riskier than men to inform that prefer bosses who respect, trust and guide the team than to receive a wage according to responsibilities and a benefits package that meets their needs $(p<0.01)$. This result is compatible with that presented by Štefko et al. (2017), as the authors observed that women, in relation to men, declared to be less motivated at work when they perceive unjust conduct by their superiors. 
The subsequent aspects that women are more likely to prefer than men in relation to wage and benefits package are: satisfaction and motivation with work ( $r r=1.7 ; p=0.01$ ), the balance of work and personal life ( $r r r=1.6 ; p=0.04)$, and learning, growth, and development in the company ( $r r r=1.6 ; p=0.01$ ). Such preferences indicated by women might be associated with issues, for instance: when compared to men, women had a late entry into the labor market; and the level of occupation of women is lower than that of men in Brazil, id est, women are underrepresented in management and leadership occupations. For these reasons, women might be more concerned with issues associated with professional training and development at work, as well as with satisfaction and motivation and balance between life and work. It is also noteworthy that policies providing a balance between work and personal life, despite being offered to men and women, benefit especially women, improving their experiences in the work environment (Feeney \& Stritch, 2019). The last two aspects that present a gender difference when compared to receiving adequate wages and benefits are: agreeing with the company's goals and values and being proud to work for it $(p=0.07)$ and being recognized for their dedication and new ideas $(p=0.09)$. In these two cases, women are 1.4 times riskier than men to prefer the intangible aspects over the tangible.

Alternatively, to detail the results of the research, a model was tested in which the control variables had a moderating relationship with gender. Moderation allows detailing the level of gender interaction in each of the categories of independent variables, making it possible to present gender differences for each of the respondents' profile characteristics. The Pseudo- $R^{2}$ was slightly higher than that of the original model (3.9\%), it was not possible to reject the null hypothesis of the Hosmer-Lemeshow test $\left(\chi^{2}=81 ; d f=80 ; p=0.45\right)$ adapted to the MLR (Fagerland \& Hosmer, 2012) and it was possible to reject the null hypothesis of the general model that all parameters are equal to zero $\left(\chi^{2}=737.8 ; d f=260 ; p<0.01\right)$.

The intangible aspects "admiring what the company does for its customers, society, and the community" and "having stability and security" continued with invariance between genders when compared to the tangible aspect. The results of Štefko et al. (2017) pointed out that women, more than men, feel discouraged when they are susceptible to a job instability scenario. This apparent contradiction between the results of this research and Štefko et al.'s (2017) can be explained by the characteristics of the sample. While the present study deals with companies that may be among the best in the industry, Štefko et al. (2017) studied small and medium-sized companies. Another aspect that can explain this distinction is the influence of different institutional factors, such as cultural, political, and social issues, in the respondents' perception. The mentioned study investigated the Slovak context, in Eastern Europe, whereas the present research analyzed the Brazilian context, in South America, two scenarios involved in different realities. We understand that this contrast becomes an incentive for the development of investigations that consider different contexts so that it is possible to understand the theme with increasing depth. Moreover, a further contrast between the sample characteristics is related to the sample of Štefko et al. (2017), which has almost 20pp more women than the number of men.

The other two categories that showed no difference in the main model, reveal, for the first time, the greater probability of choosing an intangible aspect as "being in an environment of good relations with co-workers" ( $p=0,03$ for men with an undergraduate degree and $p=0.01$ for men with postgraduate degree) and "to be treated fairly" ( $p=0.09$, also among men). Not only these, but other categories also indicated that men have a preference for intangible aspects, such as those with an undergraduate degree who prefer a balance in the relationship between work and personal life $(p=0.04)$ and those with a postgraduate degree who prefer compatibility with 
organizational values and objectives $(p=0.09)$, both in relation to those with only high school education.

The educational level is the only variable that has a moderating relationship with the male gender. Men with graduate or postgraduate degrees are more likely to choose an intangible aspect. The most prominent categories are: postgraduate men are 3.6 times riskier to choose a company as an excellent place to work when they perceive that they are learning and have an opportunity for growth and development $(p=0.07)$ and three times when they are recognized for their dedication $(p=0.08)$. Despite the lower level of evidence $(0.1>p>0.05)$, we find that this result relates the higher level of education with the intangible preference of learning and growth. This employee profile knows that grew opportunities could lead to better conditions, like higher salaries, promotion, and career development.

When the wage moderates the gender variable, we further observe a preference for intangible reasons by women, specifically women who earn more than four minimum wages at the expense of those who earn a maximum of two. This women profile is 3.5 times riskier when the intangible aspect is to agree with the company's goals and values $(p=0.04)$, five times when we analyze the insertion in an environment of good relationships with colleagues $(p=0.05)$ and fifteen times when it comes to having respectable, trustworthy bosses who guide the work team $(p=0.03)$. The other moderations - not mentioned in the text - showed no significant difference between men and women. As previously discussed, we point that the profile characteristics can explain those differences of preference. The majority of the male workforce is focused on the operations of the construction sector. These low-income activities could impact to choose the company as a better place to work if their salaries increase. The women profile, nearest to the described in the last paragraph, with higher education levels, hides a better social condition that enables to prefer intangible aspects than the tangible ones.

In short, there is a prevalence of opting for intangible aspects - agreeing with the company's goals and values and having respectable and trustworthy bosses, over tangible aspects (wage and benefits) - by women, as observed in the two models presented. Probably the tangible aspects do not stand out because there is still a macho cultural heritage and a sexual division of labor present in society, as women had a late entrance in the labor market, as a result of socioeconomic transformations and feminist movements that began in the 20th century (Sorj et al., 2007). In this sense, women often tend to "exchange" a high salary for other attributes at work (Vokić, Ćorić, \& Obadić, 2017). These results may be associated with the fact that they attach greater importance to the inclusive workplace, compared to good remuneration, especially in a sector where diversity is minimal.

\section{FINAL CONSIDERATIONS}

From the results obtained, we observe that women are more likely to consider intangible than tangible aspects (in this case, only the wage and benefits) when compared to men in defining an excellent place to work. For women, six intangible aspects were prominent, namely: (1) having respectable bosses who guide the work team; (2) job satisfaction and motivation; (3) work-life balance; (4) possibility of learning, growth, and development; (5) agree with the company's objectives and be proud to work for it; and (6) being recognized for dedication and new ideas. The other four intangible factors are significantly homogeneous between genders.

Regarding the moderation of profile variables in the relationship between gender and the choice for a reason that makes a company to be considered excellent to work, the characteristics of 
educational level are responsible for moderating the increase in the probability of men in choosing some intangible aspects, specifically when they have higher education. On the other hand, in certain comparisons, women with higher wage levels are more likely to choose intangible aspects in defining an excellent place to work.

Given the perceived differences between men and women, it is clear the importance of offering socially responsible HR practices, including the possibility of equitable growth (Frangieh \&Yaacoub, 2019), since "gender equality is achieved when opportunities for all types are equally available for men and women"(Kim et al., 2019, p. 2). The civil construction sector was chosen precisely because of the discrepancy between men and women and, when analyzing the predominance of men in relation to the participation of women, the proportion indicated by IBGE is similar to that found in the present study: $89.8 \%$ and $83 \%$, respectively. Such similarity is an indication that the results presented in this research can be inferred about the Brazilian population in the civil construction sector. On the other hand, the results may underestimate the gender differences as the companies are listed among the best ones to work for.

The control variables age, internship (versus non-intern), and hired under CLT (versus not hired under CLT) showed differences in the choice of at least five of the ten intangible aspects in relation to wage. Future studies could seek to understand the gender and age differences (or career stages) that make an organization an excellent place to work, since, according to Souza et al. (2015), individuals change expectations regarding the characteristics of work throughout their lives.

The study delimitation is supported by the comparison between several tangible aspects with a tangible aspect, the receipt of wages and benefits. Future researches could use other strategies and (a) use variables that measure other tangible aspects, (b) compare intangible aspects with each other, (c) rank or assign weights to each aspect, instead of analyzing categories of unique responses. From these three topics, it is possible to derive three limitations of the present study: (1) the availability of only one variable that measures tangible aspects; (2) the research parsimony does not allow the comparison of all pairwise combinations of the dependent variable categories; and (3) the respondents only pointed to one category, when, in fact, the phenomenon of choosing a company as an excellent place to work can occur due to the combination of several factors.

Finally, another issue that emerges as a limitation is that a representative portion of the respondents works at the operational level, that is, the results obtained in this research may represent a bias, to some extent. Considering this, we suggest the development of studies that perform stratification by occupational space, enabling dialogue with our findings.

\section{ACKNOWLEDGMENTS}

This work was supported in part by grants from CAPES - Brazilian Federal Agency for Support and Evaluation of Superior Education -, within the Ministry of Education of Brazil, and CNPq Brazilian National Council for Scientific and Technological Development -, within the Ministry of Science and Technology of Brazil. We also thank the Fundação Instituto de Administração (FIA) through the People Management Studies Program (PROGEP), which allowed access to the analyzed data.

The authors are grateful for the contributions received from anonymous reviewers. 


\section{REFERENCES}

ALMEIDA, T. A., MORAIS, C. R. F., \& COELHO, A. C. (2020). Gender diversity, governance and dividend policy in Brazil. Revista de Gestão, 27(2), 189-205.

BERALDO, G. S., \& TRINDADE, E. (2016). Novos Pais, Novos Homens? Paternidade e Identidade masculina no Contexto Pós-Moderno. Pretextos-Revista da Graduação em Psicologia da PUC Minas, 1(2), 56-75.

CATANO, V. M., \& HINES, H. M. (2016). The influence of corporate social responsibility, psychologically healthy workplaces, and individual values in attracting millennial job applicants. Canadian Journal of Behavioural Science, 48(2), 142-154.

CAVAZOTTE, F. D. S. C. N., LEMOS, A. H. D. C., \& VIANA, M. D. D. A. (2012). Novas gerações no mercado de trabalho: expectativas renovadas ou antigos ideais?.Cadernos Ebape.br, 10(1), 162-180.

CAVERO-RUBio, J. A., COLLAZO-MAZÓN, A., \&AMORÓS-MARTínEZ, A. (2019). Public recognition of gender equality in the workplace and its influence on firms' performance. In Women'sStudiesInternationalForum, 76, 1-12.

DANTAS, I. (2017). Depreciação, amortização e exaustão do ativo imobilizado/intangível: contabilidade societária \& fiscal. Rio de Janeiro: Freitas Bastos. 268 p.

DEL FIACO, J. L. M. \& MELO, N. P. (2011). Gestão de pessoas - do tangível ao intangível: o valor que esta gestão pode agregar ao desenvolvimento organizacional. Gestão, Inovação e Negócios, (6), 47-70.

FADEL, M. A. V., \& REGIS FILHO, G. I. (2009). Percepção da qualidade em serviços públicos de saúde: um estudo de caso. Revista de Administração Pública, 43(1), 7-22.

FÁVERO, L. P. L., BELFIORE, P. P., SILVA, F. L. D., \& CHAN, B. L. (2009). Análise de dados: modelagem multivariada para tomada de decisões. Rio de Janeiro: Elsevier.

FAGERLAND, M. W., \& HOSMER, D. W. (2012). A Generalized Hosmer-Lemeshow Goodness-of-Fit Test for Multinomial Logistic Regression Models. The Stata Journal: Promoting Communications on Statistics and Stata, 12(3), 447-453.

FEENEY, M. K., \& STRITCH, J. M. (2019). Family-Friendly Policies, Gender, and Work-Life Balance in the Public Sector. Review of Public Personnel Administration, 39(3), 422-448.

FRANGIEH, C. G., \&YAACOUB, H. K. (2019). Socially responsible human resource practices: disclosures of the world's best multinational workplaces. Social ResponsibilityJournal, 15(3), 277-295.

IBGE. Instituto Brasileira de Geografia e Estatística (2018). Estatísticas do Cadastro Central de Empresas: 2016. Rio de Janeiro: IBGE, 2018. Recovered from https://biblioteca.ibge.gov.br/ visualizacao/livros/liv101590.pdf.

IBGE. Instituto Brasileira de Geografia e Estatística (2019). Estatísticas do Cadastro Central de Empresas: 2017. Rio de Janeiro: IBGE, 2019. Recovered from https://biblioteca.ibge.gov.br/ 
visualizacao/livros/liv101658.pdf.

KAYO, E. K., \&FAMÁ, R. (2004). A estrutura de capital e o risco das empresas tangível-intensivas e intangível-intensivas. Revista de Administração da Universidade de São Paulo, 39(2), 164-176.

KIM, K. Y., ATWATER, L., JOLLY, P. M., KIM, M., \&BAIK, K. (2019). The Vicious Cycle of Work Life: Work Effort Versus Career Development Effort. Group \& Organization Management, 1-35.

KOLPAKOVA, J., MAY, M. W., \& MAAR, U. (2019). Workspace management as a part of FM mission: a study of German FM education. Facilities, 37(13/14), 995-1007. https://doi. org/10.1108/F-12-2017-0117

KURT, Y., SINKOVICS, N., SINKOVICS, R. R., \&YAMIN, M. (2020). The role of spirituality in Islamic business networks: The case of internationalizing Turkish SMEs. Journal of World Business, 55(1), 1-15.

LEE, H. W., ROBERTSON, P. J., \& KIM, K. (2019). Determinants of Job Satisfaction Among US Federal Employees: An Investigation of Racial and Gender Differences. Public Personnel Management, 1-31.

LINDBERG, P. \&VINGÅRD, E. (2012). Indicators of healthy work environments - a systematic review. Work, 41(1), 3032-3038. https://doi.org/10.3233/WOR-2012-0560-3032

MORIN, E. M. (2001). Os sentidos do trabalho. Revista de Administração de Empresas, 41(3), 8-19.

OISHI, A. S., CHAN, R. K., WANG, L. L. R., \& KIM, J. H. (2015). Do part-time jobs mitigate workers' work-family conflict and enhance wellbeing? New evidence from four East-Asian societies. Social Indicators Research, 121(1), 5-25.

RIZZO, C. B. D. S., \&CHAMON, E. M. Q. D. O. (2010). O sentido do trabalho para o adolescente trabalhador. Trabalho, Educação e Saúde, 8(3), 407-417.

SLOAN, M. M. (2017). Gender differences in commitment to state employment: The role of coworker relationships. Public Personnel Management, 46(2), 170-187.

SORJ, B., FONTES, A., CARUSI, D., \&QINTAES, G. (2007). Reconciling work and family: issues and policies in Brazil. Cadernos de Pesquisa, 37(132), 573-594.

SOUSA, L. P. D., \& GUEDES, D. R. (2016). A desigual divisão sexual do trabalho: um olhar sobre a última década. Estudos Avançados, 30(87), 123-139.

SOUZA, P. M. R. A., LOPES, A. L. S. V., \&HILAL, A. V. G. (2015). Características do Trabalho Valorizadas por Trabalhadoras de Diferentes Faixas Etárias. Revista de Administração FACES Journal, 14(4), 107-126.

ŠTEFKO, R., BACIK, R., FEDORKO, R., GAVUROVA, B., HORVATH, J., \&PROPPER, M. (2017). Gender differences in the case of work satisfaction and motivation. Polish Journal of ManagementStudies, 16.

VILELA, N. G. S., HANASHIRO, D. M. M., \& COSTA, L. S. (2020). (Des)igualdade de gênero no local de trabalho e práticas de recursos humanos. Revista Alcance, 27(3), 382-398. https://doi. org/10.14210/alcance.v27n3(Set/Dez).p382-398 
VOKIĆ, N. P., ĆORIĆ, D. S, \&OBADIĆ, A. (2017). To be or not to be a woman?-Highly educated women's perceptions of gender equality in the workplace. Revijaza socijalnupolitiku, 24(3), 253-276.

WAINWRIGHT, D., CRAWFORD, J., LORETTO, W., PHILLIPSON, C., ROBINSON, M., SHEPHERD, S., ... \&WEYMAN, A. (2018). Extending working life and the management of change. Is the workplace ready for the ageing worker?.Ageing \& Society, 39(11), 2397-2419.

WEBBER, K. L., \& ROGERS, S. M. (2018). Gender Differences in Faculty Member Job Satisfaction: Equity Forestalled? Research in Higher Education, 59(8), 1105-1132.

\section{AUTHORS}

\section{Nágila Giovanna Silva Vilela}

Ph.D. candidate in People Management at the School of Economics, Business and Accounting - University of São Paulo (FEA/USP). Master's degree in Business at Federal University of Paraná (UFPR). Professor at Faculty of Business and Economic Sciences (FACEC).

E-mail: nagilavilela@gmail.com

ORCID: https://orcid.org/0000-0002-8279-2763

\section{Lucas dos Santos Costa}

Ph.D. student at Business at School of Economics, Business and Accounting at the University of São Paulo (FEA/USP). Master in Business (FEA/USP). Lecturer at FIA Business School.

E-mail: adm.lucassantos@hotmail.com ORCID: https://orcid.org/0000-0002-0979-3567

\section{Ronaldo de Oliveira Santos Jhunior}

Ph.D. candidate in Business Administration at the School of Economics, Business and Accounting - University of São Paulo (FEA/USP). Master's degree in administration with studies in Strategy and Organizational Analysis at the Federal University of Paraná (UFPR). Works in academic editorial management and teaches in graduate classes in international business at the Alvares Penteado School of Commerce Foundation (FECAP).

E-mail: ronaldojhr@gmail.com

ORCID: https://orcid.org/0000-0003-0867-7916

\section{Adrian Ilie Olar}

Master's in finance at Tilburg University, The Netherlands. Bachelor's in Accounting and Management Information Systems at Bucharest University of Economic Studies, Romania.

E-mail: a.olar@uvt.nl

ORCID: https://orcid.org/0000-0002-6100-2988 


\section{Contribution of authors.}

Every author should account for at least one component of the work. Paper approved for publication need to specify the contribution of every single author.

\begin{tabular}{|l|c|c|c|c|}
\hline \multicolumn{1}{|c|}{ Contribution } & [Author 1] & [Author 2] & [Author 3] & [Author 4] \\
\hline 1. Definition of research problem & $\mathrm{V}$ & $\mathrm{V}$ & & \\
\hline $\begin{array}{l}\text { 2. Development of hypotheses or research } \\
\text { questions (empirical studies) }\end{array}$ & $\mathrm{v}$ & $\mathrm{V}$ & $\mathrm{V}$ & \\
\hline $\begin{array}{l}\text { 3. Development of theoretical propositions } \\
\text { (theoretical work) }\end{array}$ & & & & \\
\hline 4. Theoretical foundation / Literature review & $\mathrm{V}$ & $\mathrm{V}$ & $\mathrm{V}$ & $\mathrm{V}$ \\
\hline 5. Definition of methodological procedures & $\mathrm{V}$ & $\mathrm{V}$ & & \\
\hline 6. Data collection & $\mathrm{V}$ & & & \\
\hline 7. Statistical analysis & & $\mathrm{V}$ & & \\
\hline 8. Analysis and interpretation of data & $\mathrm{V}$ & $\mathrm{V}$ & $\mathrm{V}$ & \\
\hline 9. Critical revision of the manuscript & & & $\mathrm{V}$ & $\mathrm{V}$ \\
\hline 10. Manuscript writing & $\mathrm{V}$ & $\mathrm{V}$ & $\mathrm{V}$ & \\
\hline 11. Other (please specify) & & & & \\
\hline
\end{tabular}

\section{Conflict of Interest}

The authors have stated that there is no conflict of interest.

\section{Copyrights}

ReA/UFSM owns the copyright to this content.

Plagiarism Check

The ReA/UFSM maintains the practice of submitting all documents approved for publication to the plagiarism check, using specific tools, e.g.: CopySpider. 